\title{
Toward the Etymology of Latin littera
}

\author{
Václav Blažek \\ (Masaryk University, Brno)
}

\begin{abstract}
In the present contribution the Latin word littera is anylazed from the point of view of etymology. First, the previous relevant etymological attempts are discussed. If none of them is convincing enough to exclude doubts, a new etymology is proposed. It is based on supposition that the script may also be named according to material, here namely "linen cloth", really used in the ancient Mediterranean world. A source of Latin littera could be Greek acc.sg. "lita "linen cloth", mediated to Romans via Etruscans, adding the plural in -er-.
\end{abstract}

\section{Keywords}

Latin; Etruscan; Greek; Semitic; etymology; letter; script; linen cloth 
0 . The Latin word littera and its derivatives belong to the most wide-spread cultural terms of Latin origin, adopted by almost all modern languages of Europe. In the present study its orthographic variants and existing etymologies are discussed. Finally a new etymological solution is proposed.

\section{Variants and the internal reconstruction:}

1.1. The Latin term littera is known first from the comedy Tarentilla [verse 79] by Naevius (c. 270-201 BCE), mediated by Isidore of Seville [Orig. 1.26.2]:

\section{${ }^{74}$ Quasi pila}

${ }^{75}$ in choro ludens datatim dat se et communem facit.

${ }^{76}$ Alii adnutat, alii adnictat, alium amat alium tenet.

${ }^{77}$ Alibi manus est occupata, alii pervellit pedem;

${ }^{78}$ anulum dat alii spectandum, a labris alium invocat,

${ }^{79}$ cum alio cantat, at tamen alii suo dat digito litteras.

"As though she were playing at ball, give-and-take in a ring, she makes herself common property to all men. To one she nods, at another she winks; one she caresses, another embraces. Now elsewhere a hand is kept busy; now she jerks another's foot. To one she gives her ring to look at, to another her lips blow a kiss that invites. She sings a song with one; but waves a message for another with her finger." 1

"Tossing from hand to hand in a ring of players like a ball, she gives herself and makes herself common. She embraces one, nods to another, and her hand is occupied with yet another, she pinches the foot of another, gives to another a ring to look at, calls another by blowing a kiss, sings with another, and to still others gives signals with her finger." ${ }^{2}$

In a similar sense "script, scripture, writing, letter / Schrift, Schriftstück, Schreiben, Brief”, although with a rather metaphorical value, and with the geminate, the word was also used by Plautus (c. 254-84 BCE):

Bacchides 3.2.5-6/389: ex Epheso huc ad Pistoclerum meum sodalem litteras misi

"from Ephesus I sent letters hither to my friend Pistoclerus"3

More frequently Plautus used the word in the sense "letter / Buchstabe":

Aulularia 1.1.37-39/76ff. neque quicquam meliust mihi, ut opinor, quam ex me ut unam faciam litteram longam, meum laqueo collum equando obstrinxero

“... and there isn't anything better for me, as I fancy, than to make one long capital letter of myself, when I've tied up my neck in a halter."

1 Transl. by Eric Herbert Warmington (1936: pp. 99-01).

2 Transl. by Stephen A. Barney et al. (2010: p. 52).

3 Transl. by Henry Thomas Riley (1875: p. 171).

4 Transl. by H. T. Riley (1875: p. 378). 
Asinaria 4.1.22/767: ${ }^{16}$ aut quod illa dicat peregre allatam epistulam, ${ }^{17}$ ne epistula quidem ulla sit in aedibus ${ }^{18}$ nec cerata adeo tabula; et si qua inutilis ${ }^{19}$ pictura sit, eam vendat: ni in quadriduo ${ }^{20}$ abalienarit, quo abs te argentum acceperit, ${ }^{21}$ tuos arbitratus sit, comburas, si velis, ${ }^{22}$ ne illi sit cera, ubi facere possit litteras.

"Or, because she may affirm that the letter has been brought from abroad, there is not to be even any letter in the house, nor so much as a waxed tablet; and if there is any useless picture, let her sell it; if she does not part with it, within four days from the time when she has received the money of you, let it be considered as your own; you to burn it if you like; so that she may have no wax, with which she may be able to make a letter." 5

1.2. One of the first editors of Plautus, Domitius Palladius (c. 1460-1533), printed some forms with the simple -t:: e.g. Bacch. 730 literas, Merc. 303 literarum (Persson 1917: p. 131).

The parallel situation is known from the epigraphic evidence, where both, -tt- and -t- occur:

Geminated -tt-: littera [CIL I ${ }^{2}$ 588.10; 78 BCE], [CIL I² 203.10].

Simple -t-: leiteras [CIL I ${ }^{2}$ 198.34; 123/122 BCE]; litera [CIL I $\left.{ }^{2} 207\right]$.

Weiss (2010) analyzes the conditions allowing the vacillation $\bar{V} T \sim \breve{V T T}$. He concludes, the rule $\bar{V} T \rightarrow \breve{V T T}$ is valid, if $V$ is a high vowel and $T$ a voiceless stop. This means that the primary starting-point of the analyzed forms should be *intera.

1.3. In Latin the process of monophthongisation $*_{e} i>*_{e}^{-}>*_{\bar{\imath}}$ was completed around 150 BCE, although the spelling $e i$ for $\bar{\imath}$ (and even $\grave{\imath}$ ) was still applied in the first centuries CE (Leumann \& Hofmann 1928: pp. 76-78, §57), e.g. ueiuam [CIL I ${ }^{2}$, 1837] versus correct uiuam for *uĩuam $\rightarrow{ }^{*} g^{\varkappa} i H_{3} u o-$; see Meiser (1998: p. 49, §39.4; p. 58, §47.2) and even seine [CIL I ${ }^{2}$ 583.54] for š̃ne (Persson 1917: p. 131; Leumann \& Hofmann 1928: p. 78). In the inscription documented in CIL I ${ }^{2}, 1430$, ivnone seispitei matri, there are three various realisations of the diphthong *ei (cf. Leumann \& Hofmann 1928: p. 270, §189a; Kent 1946: p. 40, §251; Tronskij 2001: p. 169, §358).

\section{Existing etymologies}

There are several etymological attempts, beginning already from the ancient grammarians:

2.1. Diomedes, Ars grammatica (end of the $4^{\text {th }}$ cent. CE): Littera dicta quasi legitera, quia legitur, vel quod legentibus iter ostendit, vel a litura quam patitur, vel quod legendo iteratur.

2.2. Ross (1853: p. 293): Adaptation of Greek $\delta i \varphi \theta \dot{\varepsilon} \rho a$ "skin", pl. "writing-material” (before import of papyrus) [Herodot 5.58] with the 'Sabine' change $d>l$ (dingua [Marius Victorinus] : lingua [Lex XII], dacrima : lacrima [Andronicus], usually lacruma), or Latin

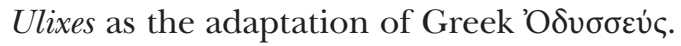

5 Transl. H. T. Riley (1875: p. 515). 
2.3. Vaniček (1874: p. 137): Derivative of the Latin verb lǐnō, lēevi, litum "to daub, besmear, anoint, spread, rub over (also about script)". The following development was reconstructed e.g. by Persson (1917: pp. 131-132) and Muller (1926: p. 235). They proposed as the starting-point the collective *leitesa , formed from the neuter $s$-stem *leitos. Persson (1917: p. 132), followed by Walde \& Hofmann (1938: p. 815), added the semantic parallel

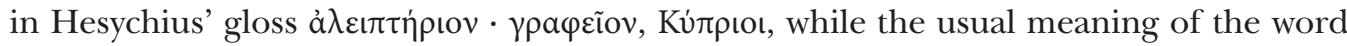
$\dot{\alpha} \lambda \varepsilon \imath \tau \tau \dot{p} \rho ı v$ is "a place for anointing in gymnastic schools, or among the Romans at the baths, used also as a sudatory". Painting letters is really very close to daubing or smearing. But the assumed morphological scenario was rejected by de Vaan (2008: p. 346).

Walde \& Hofmann (1938: p. 815) quoted still two, less convincing, etymological attempts: 2.4. Wood (1926: p. 97) reconstructed littera < *slituera * "engraving" on the basis of the Gothic verb ga-sleipjan "to damage, harm".

2.5. Güntert (1928: p. 135) thought about a connection with Latin lituus "curved staff of augurs" [Ennius].

2.6. Most recently Weiss (2010: p. 1) derives Old Latin leitera from the root *leit- "to scratch". From the point of semantics such a development is quite natural, cf. Latin scrībere "to write" [Naevius]: Latvian skrīpât "to scratch, scribble, write down", Middle Irish scrīp(a)id "scratches" (cf. de Vaan 2008: pp. 546-547) or Old High German riz "scratching, line, letter" (Kroonen 2013: p. 597). But it is not clear, which concrete material led $\mathrm{M}$. Weiss to this reconstruction.

3.1. There were various techniques of writing. Besides engraving or carving, usually on stone or wood, the letters were also painted, e.g. on cloth, papyrus, skin, bark or bast. And these materials could inspire new designations of writing or letters. A fitting ex-

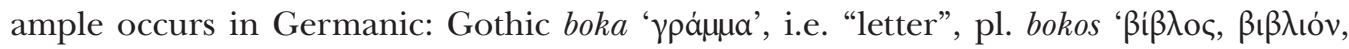

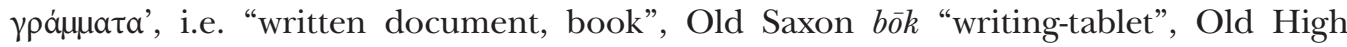
German buoh "book, script, scripture, letter" etc., all from Germanic *bōk $(j) \overline{o^{-}}$"beech" (Lehmann 1986: p. 77; Kroonen 2013: p. 71). Perhaps Balkan Gothic is a source of South Slavic *buky "letter", pl. "book, written document", mediated via Church Slavonic into East Slavic (see the discussion by Pronk-Tiethoff 2013: pp. 80-82).

The Romans designated their books as liber [from Plautus], whose primary meaning was "bark of a tree", confirmed by cognates in other Indo-European branches: Albanian labe ".rind, cork", Prussian lubbo "bast, plank, shelf", Lithuanian lúobas "bark, rind of a tree", Russian lub "bast" etc. (de Vaan 2008: p. 337). In this perspective it is tempting to mention the Roman tradition described by Titus Livius on Liber linteus "Linen book", which should be stored in the temple of Juno Moneta:

[4.7.12] nomina consulum horum Licinius Macer auctor est et in foedere Ardeatino et in linteis libris ad Monetae inventa.

"Licinius Macer states, that they were found both in the Ardean treaty and in the linen books at the temple of Moneta." ${ }^{\prime}$

6 Transl. D. Spillan (1853: p. 259). 
[4.20.8] quis ea in re sit error, quod tam veteres annales quodque magistratuum libri, quos linteos in aede repositos Monetae Macer Licinius citat identidem auctores, septimo post demum anno cum T. Quinctio Poeno A. Cornelium Cossum consulem habeant, existimatio communis omnibus est.

"Whether the mistake is chargeable on the very ancient annals and the linen books of the magistrates, deposited in the temple of Moneta, and which Licinius Macer occasionally cites as authorities, which have Aulus Cornelius Cossus consul with Titus Quintius Pennus, in the ninth year after this, every person may form his own opinion."7

The tradition of writing long texts on linen cloth was borrowed by the Romans from the Etruscans, probably together with the script. After all, the longest known Etruscan text was done on linen. It is called as Liber linteus \{Zagrabiensis\} and was discovered in Croatian Zagreb (details see e.g. van der Meer 2008; Urbanová \& Blažek 2008: p. 59). If the script had been brought into ancient Italy by Greeks, it would not be surprising, if the Greeks had also mediated linen-cloth as the writing-material.

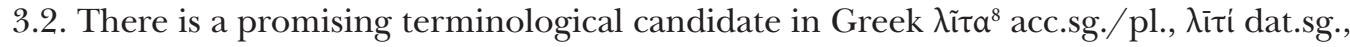
"linen cloth" [Il. 18.352, 23.254; Od. 1.130, 10.353]. The term is identified already in the Mycenaean texts from Knossus as ri-ta adj. nom.pl.ntr. "linen" [KN L 567.2] (Aura Jorro 1993: p. 257). If the root $\lambda \bar{\imath}^{\circ}$ was adopted into Etruscan, it is expected that it would have been accommodated to the Etruscan substantive declension. In the nom.pl. it should look like *liter and in the gen.pl. like *līteras, cf. Etruscan nom.sg. ais "god", nom.pl. aiser, gen.pl. aiseras (Steinbauer 1999: pp. 90, 395; about the possibility to identify here the Etruscan plural in -ar-, see Deroy 1975: p. 53; but his assumption to reconstruct Etruscan *litara "sign" is not convincing, cf. Lejeune 1993: p. 11). ${ }^{9}$

3.3. A contamination of Latin linum "flax plant, linseed; linen" [Naevius] and Greek $\lambda \bar{i} \tau^{\circ}$ "linen cloth" could explain the rather enigmatic Latin linteum "piece of linen cloth, towel, sail" [Plautus], with shortening of $\bar{\imath}$ before $-n t$ - in agreement with Lex Osthoff.

3.4. Finally, let us mention that Greek $\lambda \bar{\imath} \tau^{\circ} \&$ Mycenaean ri-ta are probably of Semitic origin, cf. Akkadian lītu / lẹtu / lițtu, pl. lițtêtu "a garment or cloth as bed covering" (CDA 183; see Astour 1965: p. 338; probably independently identified by Szemerényi 1977: p. 3; Rosól 2013: p. 188, with a detailed discussion and sources). Interesting is the New Assyrian homonym lițu / lițtu "sketch, drawing" (CDA 183), which can develop from the material for drawing.

7 Transl. D. Spillan (1853: p. 273).

8 Cf. an unambiguous analysis of this term by Vijūnas (2006: pp. 108-114) from the Indo-European perspective.

9 Cf. Ernout \& Meillet (1932: pp. 528-529): “... il n'est pas invraisemblable que littera lui-même soit, directement ou indirectement, d'origine grecque... Un emprunt pour voie étrusque est possible.” 


\section{Bibliography}

Astour, M. C. (1965). Hellenosemitica. An Ethnic and Cultural Study in West Semitic Impact on Mycenaean Greece. Leiden: Brill.

Aura Jorro, F. (1993). Diccionario micénico (Vol. II). Madrid: Consejo superior de investigaciones científicas.

Barney, S. A., Lewis, W. J., Beach, J. A., \& Berghof, O. (Eds.). (2010). Isidore of Seville: Etymologies (with the collaboration of Muriel Hall). Cambridge: University Press.

$C D A=$ Black, J., George, A., \& Postage, N. (Eds.). (2000). A Concise Dictionary of Akkadian. Wiesbaden: Harrassowitz.

Deroy, L. (1975). 'Lettre' et 'litre', deux mots d'origine étrusque. Les Études Classiques, 43, 45-58.

Ernout, A., \& Meillet, A. (1932). Dictionnaire étymologique de la langue latine. Histoire des mots. Paris: Klincksieck.

Güntert, H. (1928). Weiteres zum Begriff Winkel im ursprünglichen Denken. Wörter und Sachen, $11,124-142$.

Kent, R. G. (1946). The Forms of Latin, a Descriptive and Historical Morphology. Baltimore: Linguistic Society of America.

Kroonen, G. (2013). Etymological Dictionary of Proto-Germanic. Leiden - Boston: Brill.

Lehmann, W. P. (1986). A Gothic Etymological Dictionary. Leiden: Brill.

Lejeune, M. (1993). Le nom de mesure 入ítpa: essai lexical. Revue des études grecques, 106(1), 1-11.

Leumann, M., \& Hofmann, J. B. (1928). Lateinische Grammatik. Laut- und Formenlehre. Syntax und Stylistik. München: Beck.

van der Meer, L. B. (2008). Liber linteus Zagrabiensis. The Linen Book of Zagreb. A Comment on the Longest Etruscan Text (Monographs on Antiquity, 4). Louvain - Dudley (M.A.): Peeters.

Meiser, G. (1998). Historische Laut- und Formenlehre der lateinischen Sprache. Darmstadt: Wissenschaftliche Buchgesellschaft.

Muller, F. (1926). Altitalisches Wörterbuch. Göttingen: Vandenhoeck \& Ruprecht.

Persson, H., \& Persson, P. (1917). Zur lateinischen und griechischen Wortforschung. Zeitschrift für vergleichende Sprachforschung auf dem Gebiete der indogermanischen Sprachen, 48(1/2), 121-136.

Pronk-Tiethoff, S. (2013). The Germanic Loanwords in Proto-Slavic. Amsterdam - New York: Rodopi. Riley, H. T. (Transl.). (1875). Plautus: The Comedies of Plautus (Vol. I). London: G. Bell and Sons.

Rosół, R. (2013). Frühe semitische Lehnwörter im Griechischen. Frankfurt am Main: Lang.

Roß, L. (1853). Zur Etymologie. Rheinisches Museum für Philologie, 8, 292-297.

Steinbauer, D. H. (1999). Neues Handbuch des Etruskischen. St. Katharinen: Scripta Mercaturae Verlag.

Spillan, D. (Transl.). (1853). The History of Rome, by Titus Livius. Book IV. London: s.n.

Szemerényi, O. (Rew.). (1977). Pierre Chantraine: Dictionnaire étymologique de la langue grecque. Histoire des mots (Vol. III; Paris: Klincksieck 1974). Gnomon, 49, 1-10.

Tronskij, I. M. (2001). Istoričeskaja grammatika latinskogo. Ob̌̌čeindoevropejskoe jazykovoe sostojanie (voprosy rekonstrukcii). Moskva: Indrik.

Urbanová, D., \& Blažek, V. (2008). Národy starověké Itálie, jejich jazyky a písma. Brno: Host. de Vaan, M. (2008). Etymological Dictionary of Latin and the other Italic Languages. Leiden - Boston: Brill. 
Vaniček, A. (1874). Etymologisches Wörterbuch der lateinischen Sprache. Leipzig: Teubner.

Vijünas, A. (2006). The Indo-European t-stems. Los Angeles: University of California (PhD. Diss.).

Walde, A., \& Hofmann, J. B. (1938). Lateinisches etymologisches Wörterbuch (Vol. I). Heidelberg: Winter.

Warmington, E. H. (1936). Remains of Old Latin, II: Livius Andronicus, Naevius, Pacuvius $\mathcal{E}$ Accius (Loeb Classical Library - Latin Authors, 314). London: Heinemann - Cambridge (Mass.): Harvard University Press.

Weiss, M. (2010). Observations on the Littera Rule. ECIEC XXIX, Department of Linguistics, Cornell University (June 19, 2010) [retrieved 09.11.2018 from https://www.academia.edu/1709398/ Observations_on_the_Littera_Rule].

Wood, F. A. (1926). Post-consonantal $w$ in Indo-European (Language Monographs, 3). Philadelphia: Linguistic Society of America.

Prof. RNDr. Václav Blažek, CSc. / blazek@phil.muni.cz

Department of Linguistics and Baltic Studies Masaryk University, Faculty of Arts

Arna Nováka 1, 60200 Brno, Czech Republic 
